\title{
SPECIAL PURPOSE PASTURES ON LIGHT LAND
}

By R. H. BEVIN, Senior Lecturer in Agriculture,

Canterbury Agricultural College, Lincoln.

The all-year-round feeding of stock on pasture without the aid of supplementary feed is an end greatly desired by New Zealand grass farmers. In some of the milder areas of the north this end is often achieved, but throughout the Dominion various factors operate against twelve months' grazing. These factors are climatic, geographic, and edaphic.

The climatic factor operates where, although the situation may be of low altitude and the soil. of a fertile type, the seasonal conditions-either of low summer rainfall or of severe and prolonged winter coldprevent vigorous plant growth. The geographic factors are those which are found where the latitude, altitude, or aspect of the country militate against winter growth or early spring growth. The edaphic factors are confined mainly to areas where the type of soil and/or subsoil is such that through low fertility, aridity, or water saturation the plant growth is restricted to a limited period of the year.

The story of grassland development has been one of modification of existing conditions by farmers so that pasture swards of greater or less productivity may be established and maintained. To exploit the advantages and to restrict the disadvantages of climatic and geographical effects management practices have been developed to suit local conditions. 'But to overcome difficulties presented by our various soil types much work has been needed to modify soil' fertility in order to render the land useful for pasture production.

This sustained attack on the edaphic factors is exemplified in the draining of swamps, the development of the gumlands of the north and the pumice lands of the centre of the North Island, in the liming so extensivelv used in Southland and now coming in to the foothills of Canterbury and Otago, and, in the widest sense, in the phosphatic topdressing of country of all descriptions, with or without the inclusion of trace elements acording to established needs.

A further refinement in dealing with our grass- 
land problems has been the steady progressive improvement in our pasture species types through. the research work of $\mathrm{Mr}$ Bruce. Levy arid his team of agrostologists, backed up by the certification schemes. operated' by the Department of Agriculture, so that today the farmers have at their disposal a substantial array of types which on establishment' can be guaranteed to perform according to specification ; our perennial species are truly perennial and their productivity is $\mathrm{high}$,

The work of improvement in pastures has been accompanied by the highly intelligent, utilisation of them by-farmers prepared to exploit every advantage by the regulation of the types and numbers of stock to gain a reasonably high standard of utilisation. And it is through the demand for even more efficiency in utilisation that we have come to the stage of studying in some detail the seasonal productivity of species and their ranges, of usefulness so that the "over the year" requirement of our stock may be met.

\section{STOCK ·REQUIREMENTS AND THE ANNUAL GROWTH CURVE}

There are three approaches to estimation of the stock to be carried on any property. One is to stock down' to the winter feed minimum, in which 'case wastage of feed will occur at other seasons; another is to stock 'up to cope with the spring flush, which means overstocking at other times. The third and normal method is to strike a balance between the two, providing supplementary feed in winter and conserving surplus feed in summer.

On our lighter soils in the lower-rainfall areas the bulk of the feed is produced in spring and early summer and the whole art of stocking such country lies in so regulating ewe numbers and lambing dates that as little feed as possible is wasted during the flush. Too often in the past it was the practice-and it still is on many farms. to-day-to allow the spring grass to get- ahead of the stock so that the pastures seeded freely and became in summer mere paddocks of roughage. The idea was that this would provide some measure of maintenance later in the year, but the principal effect is to encourage grass grubs, weaken the better grasses, and accelerate the deterioration to browntop and sweet vernal, all in order to provide stock with a diet of crude fibre of low feed value.

Provided that a sane approach is made to the' 
setting aside, of hay for winter feeding together with silage and/or roots and greenfeed, there is no. reason why fairly close grazing of these light land pastures should not be followed. The feed is utilised at its most nutritious stage and the perenniality or permanence of the pastures is in no way impaired.

It is important, however, to realise that species appropriate to the end in view must be sown if there is to be a reduction. in cultivation. An increase. in the period over which pasture grazing may be available to stock can be brought about- by spelling and grazing at such times as will ensure the availability of grass when the stock most require it. By the blending of species in the sward and by the establishing of specially suitable species in pure associations over the farm we can by planned management in grazing attempt to overcome some of the shortages resulting from the seasonal limitations of our basic ryegrass-white clover general purpose sward.

On the country where the main shortages occur at two seasons of the year-summer and early autumn, winter and early spring-it is not easy to provide for all requirements, but some work already done seems to indicate that with the exploitation of special purpose pastures the periods over which grazing is below requirements may be greatly reduced, even if they cannot be eliminated entirely.

The following suggestions and discussion are confined to what is generally regarded as light land; that is, land with a relatively low capital value, where the soil is subject to drying out in summer, and where winter growth is normally fairly low. Such country is devoted to the grazing sheep with the production of wool and lambs. In the native state store lambs are the rule, but with development fats, of light to medium weights, may be sold, a percentage ( 25 to 30 per cent.), off the mothers, the remainder off feed in suitable seasons with stores on occasion.

On this country some perennial species-ryegrass, white clover, and Montgomery red clover-rarely persist for more than a few years, while others, such as. cocksfoot, Phalaris tuberosa, and lucerne, show a greater expectation of life. Subterranean clover is a good basic legume in the pastures and once established and allowed. to seed freely it will persist for an indefinite period. The principle which has been adopted in making a study of the behaviour of the special purpose pastures on the light land has been that of 
devoting certain. areas to certain species so that in practice. the farm presents a checker-board appearance with the various dominants in their respective paddocks-vastly different from the uniformity found in the more fertile grasslands of the better soils and more uniform rainfall of the recognised permanent pasture areas.

Consider the seasonal contribution which the various species may. be called upon to make. Firstly, the basic grazing which extends over the autumn months of March-May and the spring months of SeptemberDecember. During the earlier period of the year the ewe flock may be treated as dry stock and their feed requirement or plane of nutrition need not be high. For ideal health the ewe should come into the early winter in good but not fat condition and from then on to lambing should be on a gradually rising plane of nutrition; she can therefore be "done a bit hard" in the weeks immediately prior to and following tupping with a short period on "flushing" feed in between. When lambing commences the ewes with their lambs can be drifted on to early spring pastures which have been reserved for them and -gradually spread over the whole farm as the feed requirements dictate. The main area for such grazing should be subterranean clover in association with ryegrass, cocksfoot, or Phalaris, of which about one third should have been spelled for as long as possible before lambing. Such pastures we have found capable of carrying about four ewes and their lambs from September to early December, more or less, depending on rainfall and seasonal conditions such as the presence or absence of drying winds.

In average seasons some lambs can be drafted in December. Early in January weaning takes place; any fats are drafted and sold while the remainder go on to fattening-feed. Under our special purpose pasture conditions this feed should be a pasture of lucerne in association with either cocksfoot or Phalaris tuberosa which. has been specially reserved from grazing for a period of 6 to 8 weeks so that it may carry sufficient feed to fatten 6 to 8 lambs per acre to 32 's.

From weaning onward ewes can be run on the dry pasturage, provided there is adequate water. If the lucerne for lamb fattening has been fed in.breaks, the earlier-finished breaks should carry enough growth in March to provide for, freshening the ewes before they are joined with the rams. 
The winter and.early spring provide a special problem. The -traditional feed is winter turnips and lupins fed off with some hay. The suggested pasturage. for this period is Phalaris tuberosa and subterranean clover, closed up in March-April and allowed to come away as greenfeed. This may be fed off in breaks, using an on-and-off system of grazing during -June, July, and August, with a run off on that portion of the basic pasture area sufficient to give them paddock room and on which lucerne hay can be fed in such quantities as are required to keep the flock moving up in condition as the winter progresses. A fair allowance of hay is $1 \frac{1}{2}$ to 2 bales per ewe. For a 1200 ewe flock this can be saved from 25 acres-50 tons plus a cut from some portion of the lucerne and cocksfoot to be reserved for the weaned lambs-say 35 tons. This gives a total of 80 tons or approximately 2500 bales of hay; 3000 bales would provide a good safe margin and would be well within reach in the better seasons.

The lambing pastures consist of the basic typesubterranean clover plus grass-which is "closed up in May. to remain ungrazed throughout the winter. The area so reserved would vary according to the season, but from observation it may be taken as being about one-third of the area in subterranean clover, leaving two-thirds to provide for ewe and hogget run off in winter. By the time this reserved "lambing" grazing has carried the ewes for 4 to 6 weeks the other paddocks will be well away, so that the flock can be dispersed over the whole area and settled down for the remainder of the spring and early summer.

The policy which has been briefly outlined is one consisting of broad suggestions for the management of light land such as is found in Canterbury, Marlborough, North Otago, and parts of the Wairarapa and Hawke's Bay, where the rainfall is under 30 inches and where summers are normally fairly dry. With the establishment of subterranean clover pastures plus lime and super phosphate, the running of increased sheep numbers probably renders the once extensive cropping policy uneconomic, at least while wool and meat prices remain high. The returns -from cultivation are often meagre and unprofitable, while the effect on soil fertility is negative. In the scheme envisaged a limited amount of cultivation for renewal of lucerne would be necessary and haymaking machinery would be required. 
A suggested set-up under such a system might be a s follow s : -

Area of farm: 800 acres.

Stock carried : 1200 ewes ; 300 ewe hoggets.

Topdressing: 1 cwt. 'super phosphate; $2 \frac{1}{2}-5$ cwt lime annually.

Cultivation: 50 acres per annum..

Area in'subterranean pasture 375 acres, of which 130 acres is reserved for lambing, leaving ' 245 acres (say. six 40-acre paddocks) to provide run off for three mobs of ewes and one of hoggets.

Area in lucerne and grass for lamb fattening, 150 acres; of which 50 acres "is saved for hay in early $\mathrm{N}$ o $\mathrm{v}$ e $\mathrm{m}$ b e $\mathrm{r}$;

Area -in Phalarïs and subterranean clover, for winter-", ing, 150 acres, say five 30-acre paddocks.

Area in lucerne, 25 acres.

Area of house paddocks for rams, killers, 50 acres.

A summary of the grazing programme would be:

$\mathrm{M}$ a r c h -

- Flush, ewes-on lucerne pasture for tupping. Close up areas for -winter grass..

Until J u n e -

- $\because$ Run- flock on subterranean pasture, closing up -f one-third of area in late May for lambing pas-

- ture.

June - July - A ugus t -

Feed stock on -hay, using winter grass fed in breaks. as green feed. -Run off on to two-thirds

"subterranean area are required.

A u " g u s t - ,

Lambed ewes drifted. on to saved pasture, ineluding lucerne, not being saved for hay.

September-December-

$\therefore$ All ewes spreád out over subterranean pasture, .r removing stock from grazed lucerne areas about mid-November.

December-

First draft of lambs. Run weaned ewes apart, from. flock.

January-

Wean. Draft. any fats and put lambs on. to saved lucerne pasture for. fattening.

J anuary - February--

After drafting cast-for-age ewes run flock. over subterranean pastures.

dne would be somewhat optimistic to think that such a scheme of pasture farming would, be adopted 
readily by our light -land.- farmers. The traditional. dependence on the plough to provide supplementary feed crops is based on years of experience, often dearly bought. In the adoption. of any modified system such as that suggested -the change-over must be gradual., As progress is made and further experience gained it is probable that the system may be developed with some confidence. One point has emerged from our observations. In the seasons when root and other forage crops grow well the pastures grow well also. In dry years there is little pasturage, but the crops are poor too. Hence, however, the supplementary feed be provided, as roots and green-feed or as pasture and green-feed, there must be on hand a good surplus of hay in order that shortages in grazing may be adequately met. Otherwise the widespread establishment of subterranean pastures and the stepping up-of stock numbers become a gamble and. the. odds are against the farmer on such land. But given a full appreciation of the hazards and a realisation of the need for adequate feed insurance which, a strong reserve of lucerne hay provides, the production per acre of some hundreds of thousands of acres of our lighter soils can be greatly increased.

The amount by which this increase will occur is not easy to define, but we have the yearly stocking figures from our Ashley Dene farm together with the results of plot experiments on the same area. The results in general terms have indicated that over 8 years the stock numbers were more than doubled. The wool production was raised from 9 th to $24 \mathrm{tb}$ per acre, while the weight of meat per acre was raised from $30 \mathrm{lb}$ to $51 \mathrm{lb}$.

The establishment of pastures has been along definite lines. In the swing over to subterranean clover and lucerne all the old pastures which were carrying a high percentage of browntop and sweet vernal were ploughed in late winter for turnips and lupins, followed. by rape to greenfeed which was ploughed in October, fallowed, and sown down from January -onwards. By this system the browntop was destroved and in our 6 to 8-year-old.subterranean pastures -has not asserted itself again. The early spring sowing of lucerne seems to have distinct possibilities, while the autumn sowing of subterranean clover -has not failed in any season. Two main hazards must be considered. One is the possible thinning out of spring-sow.n lucerne if it goes in too late and meets hot dry conditions in 
November and. December. The other is the danger of frost lift with autumn-sown clover if it is late getting awäy and encounters heavy frosts in late May and early June. Because of these hazards, well-timed cultivation and good judgment are essential for success. The drilling of all seeds has been found more satisfactory than broadcasting. This is especially the tase when soil fertility is low, as it normally is when only a light thin turf has been turned in. The sowings which have been regarded as most suitable to the purp o s e are:-

Pure lucerne :

$16 \mathrm{lb}$ seed per acre.

Lucerne and grass:

$8 \mathrm{lb}$ lucerne with

$10 \mathrm{lb}$ cocksfoot

or

7 to Phalaris tuberosa.

Subterranean clover/grass :

4 ib subterranean clover with

10-12 ib perennial ryegrass and

4-6 lb short-rotation ryegrass

o r

8-10 lb cocksfoot

or

7 th Phalaris tuberosa

using in the two latter cases 1 bushel oats as cover crop.

In the sowing of lucerne and grass the question of cross drilling is worth investigating. There seems to be a tendency when the lucerne and grass are drilled at the one operation for the grass to check. the full development of lucerne plants. If the grass- were drilled first, the ground rolled and then cross drilled with the lucerne, we might find that a more vigorous growth of lucerne would result. As a final operation the use of the heavy roller-one weighing 6 to 8 tonsis to be commended, This rolling gives consolidation of the soil and puts the stones down, so that a mower may be freely used without risk of breakages and consequent loss of time.

The application of $\frac{1}{2}$ to 1 ton of lime plus 1 cwt. super phosphate as an initial dressing is most impor- 
tant. This should be followed up annually with the equivalent of $\frac{1}{2} \mathrm{cwt}$. super and $5 \mathrm{cwt}$ of lime each year. Another point worthy of mention is the "rejuvenation "of subterranean pastures in autumn. The grubbing or heavy harrowing- of the paddocks -which are to be reserved for lambing feed has been found to result in a more vigorous growth of the clover than is found where the pasture is left undisturbed. It would seem that after several years of heavy stocking the surface soil becomes so compacted or "tight" that the seedling clover plants develop slowly. This is particularly the case where autumn rains are not heavy, though they may be adequate to promote germination. The loose stirred top on the ground definitely aids root development and well repays the effort.

The whole conception of farming the light land without continual and extensive cultivation may be regarded as somewhat revolutionary. It may be that the application of such a scheme in its entirety is impracticable. The devastating effects of drought and grass grub constitute an ever-threatening menace and cannot be disregarded or underestimated in their effects.

Nevertheless the costs incidental to constant cultivation and the uncertainty of crop returns make it worth our while to consider alternative means of husbandry and management, and it was purely to present such an alternative that this paper was submitted for your consideration and discussion, 